\title{
Flower bagging effects on the $\alpha$-mangostin content during mangosteen fruit
} growth

\author{
${ }^{1 *}$ Widodo, S.E., ${ }^{1}$ Kamal, M., ${ }^{2}$ Zulferiyenni, ${ }^{3}$ Chandra, D. and ${ }^{3}$ Kusuma, D.W. \\ ${ }^{1}$ Department of Agronomy and Horticulture, Faculty of Agriculture, University of Lampung, Bandar \\ Lampung, Lampung 35145, Indonesia. \\ ${ }^{2}$ Department of Agricultural Product Technology, Faculty of Agriculture, University of Lampung, Bandar \\ Lampung, Lampung 35145, Indonesia. \\ ${ }^{3}$ Department of Post-graduate Studies of Agronomy, Faculty of Agriculture, University of Lampung, Bandar \\ Lampung, Lampung 35145, Indonesia
}

\begin{abstract}
Article history:
Received: 26 April 2020

Received in revised form: 28

August 2020

Accepted: 18 January 2021

Available Online: 24 January 2021
\end{abstract}

\section{Keywords:}

$\alpha$-mangostin,

Bagging,

Fruit growth,

Mangosteen,

Preharvest

DOI:

https://doi.org/10.26656/fr.2017.5(S1).030

\begin{abstract}
Mangosteen fruit (Garcinia mangostana L.) is consumed mainly for two purposes, i.e., its aril for fresh or minimally processed products and its rind for herb and other health-related products. In fact, due to the high portion of rind compared to its whole fruit, its rind has a more important economic value, especially for its $\alpha$-mangostin content. This study reported the effects of flower baggings on the $\alpha$-mangostin content during mangosteen fruit growth. This field research was conducted in a farmer's field at Gisting village, Tanggamus District, Lampung Province, Indonesia. The study was arranged in a $2 \times 3$ factorial design. The first factor was bagging date [2 and 4 weeks after anthesis (WAA)], and the second one was bagging material (unbagged or control, banana 'Cavendish'paper bag, and balloon). Fruit samplings were conducted in every two weeks during the periods of 8-16 WAA. The $\alpha$-mangostin content was analyzed with HPLC [DionexUltiMate ${ }^{\circledR} 3000$, autosampler, column compartment, Ultimate 3000 pump, UV detector, column Enduro C-18 $(250 \mathrm{~mm} \times 4.6 \mathrm{~mm}, 5 \mu \mathrm{m})$ with $\mathrm{C} 18$ guard]. The results showed that the $\alpha$-mangostin content increased in a sigmoid pattern during fruit growth, and the increase was mostly not affected by bagging, bagging materials, and application periods. The $\alpha$-mangostin content increased tremendously during 10-14 WAA, regardless of bagging, bagging materials and application periods. Bagging had resulted in the decrease of $\alpha$-mangostin content during the latest period of fruit growth, regardless of bagging materials and application periods.
\end{abstract}

\section{Introduction}

Mangosteen (Garcinia mangostana L.) belongs to the family Clusiaceae or Guttiferae. Of the edible Garcinia species, mangosteen is believed to be the most important one from the economic standpoint of view. Its fruit is consumed mainly for two purposes, i.e., its aril for fresh, juice, or other processed products (Manurakchinakorn et al., 2005; Ngarmsak, 2007) and its rind for herb and other health-related products (Lim, 2012). In fact, due to the high portion of rind compared to its whole fruit, its rind has a more important economic value, especially for its $\alpha$-mangostin $\left(\mathrm{C}_{24} \mathrm{H}_{26} \mathrm{O}_{6}\right)$ content. Aizat et al. (2019) has reviewed its uses and concluded that the fruit has been utilized for various purposes, ranging from usage in industrially important products to applications in advanced technologies and biomedical innovation.

Most of the researcher efforts in mangosteen culture have been elaborated to find the cause and solution in preventing its fruit physiological disorders, in which research in yellow latex (gamboge) disorder has dominated (Jaritngam et al., 2001; Pludbuntong et al., 2007; Dorly et al., 2008; Jarimopas et al., 2009; Poovarodom, 2010; Dorly et al., 2011; Cunha et al., 2014). To inhibit physiological causes and insect attack that led to yellow latex disorder, Widodo et al. (2019) recommended that flower bagging should be applied, with the result was that paper bagging in 2 weeks after anthesis (WAA) resulted in the mangosteen fruit shelflife of 29 days compared to 4 WAA which resulted in 14 days shelf-life. The question is does flower bagging affect the $\alpha$-mangostin content in its rind tissues? Based 
on our knowledge, comparing to research in $\alpha$-mangostin as potent medicinal uses that is easily accessed (Kurniawati et al., 2010 and 2011; Wang et al., 2011; Lim, 2012; Arrosyadi et al., 2016) informations on the effects offlower bagging to $\alpha$-mangostin content are difficult to find. Therefore, this article reported the results of flower bagging on the $\alpha$-mangostin content during mangosteen fruit growth.

\section{Materials and methods}

This research that was conducted in July-December 2017, in a farmer's field at Gisting village, Tanggamus District, Lampung Province, Indonesia. The mangosteen crop samples were about 38 years old and located at 5'27'30" NL 10442'8' SL, \pm 537.1 m above-sea-level. Fruit samples for $\alpha$-mangostin were analyzed in the Laboratory of Pharmacy Analysis and Medicinal Chemistry, Fac. of Pharmacy, University of Pajajaran, Bandung, Indonesia. The research was started by tagging mangosteen flower at anthesis.

The field research used Completely Randomized Design (CRD) with three replications in each sampling period of five samplings totally. It was arranged in a $2 \times$ 3 factorial design. The first factor was bagging date [2 and 4 weeks after anthesis (WAA)], and the second one was bagging material [unbagged or control, banana 'Cavendish'- paper bag (later for easy writing on the figure, the words of cement paper bag was used), and balloon]. The reused banana 'Cavendish'- paper bags were received from Great Giant Foods, Co. Ltd., Terbanggi Besar, Central Lampung through Nusantara Tropical Farm, Co. Ltd., Labuhan Ratu, East Lampung, Indonesia. Three bagging materials (unbagged, banana 'Cavendish'- paper bag, and balloon) were applied to flowers of 2 and 4 WAA. The fruits were then sampled every 2 weeks during the fruit development periods of 816 WAA. Observations to $\alpha$-mangostin content in the rind were conducted in every two weeks sampling in the sampling periods of 8-16 WAA. The $\alpha$-mangostin content was analyzed with HPLC [Dionex-UltiMate ${ }^{\circledR}$ 3000, autosampler, column compartment, Ultimate 3000 pump, UV detector, column Enduro C-18 (250 mm $\times 4.6$ $\mathrm{mm}, 5 \mu \mathrm{m}$ ) with $\mathrm{C} 18$ guard] based on (Muchtaridi et al., 2016). Data were analyzed statistically with an orthogonal polynomial contrast at 5\% level and then presented into line graphs.

\section{Results and discussion}

Xanthone is a tricyclicisoprenylated polyphenol, with the most abundant one in mangosteen rind are $\alpha$ and $\gamma$-mangostin. Our data showed that the $\alpha$-mangostin content increased in a sigmoid pattern during fruit growth and it was increased tremendously during 10-14
WAA (Figure 1). The result was similar to Gondokesumo et al. (2019) who reported that the mangosteen at maturity level 6 of mangosteen rind has the highest total xanthones. Kurniawati et al. (2011), however, reported differently that xanthone content of mangosteen fruit's rind was not affected by fruit age because the xanthone contents at a month up to four months after anthesis were not different significantly. Consequently, as Kurniawati et al. (2011) mentioned, that green fallen mangosteen fruits might be as good the fruits of the latest maturity as the source of $\alpha$-mangostin. Unfortunately, Kurniawati et al. (2011) did not discuss sufficiently.

To inhibit physiological causes and insect attack that led to yellow latex disorder, Widodo et al. (2019) recommended that flower bagging should be applied at 2 WAA. Data in Figure 1 showed that the increase of $\alpha$ mangostin content was mostly not affected by bagging (Figure 1a), bagging materials (Figure 1e-g), and application periods (Figure $1 b-d$ ). In fact, the $\alpha$ mangostin content was increased tremendously during 10 -14 WAA, regardless of bagging, bagging materials, and application periods (Figure 1). That means when yellow latex disorder due to insect attack rises and flower bagging has to be applied, results in Figure 1 tells us that flower bagging will not affect $\alpha$-mangostin content. Bagging slightly decreased $\alpha$-mangostin content during the latest period of fruit growth (Figure 1a), regardless of bagging materials and application periods.

\section{Conclusion}

The $\alpha$-mangostin content increased in a sigmoid pattern during fruit growth, and the increase was mostly not affected by bagging, bagging materials, and application periods. The $\alpha$-mangostin content increased tremendously during 10-14 WAA, regardless of bagging, bagging materials, and application periods. Bagging had slightly decreased the $\alpha$-mangostin content during the latest period of fruit growth, regardless of bagging materials and application periods.

\section{Acknowledgement}

A special thank was directed to the General Directorate of Research Empower and Development, the Ministry of Research, Technology, and Higher Education, the Republic of Indonesia for funding this research through the National Research Grand of The Competency-based Research 2016-2018. Thanks to Great Giant Foods, Co. Ltd., Terbanggi Besar, Central Lampung through Nusantara Tropical Farm, Co. Ltd., Labuhan Ratu, East Lampung, Indonesia for providing banana 'Cavendish'-paper bags, and to Dr. Dwi Hapsoro for warm discussion during research report and 

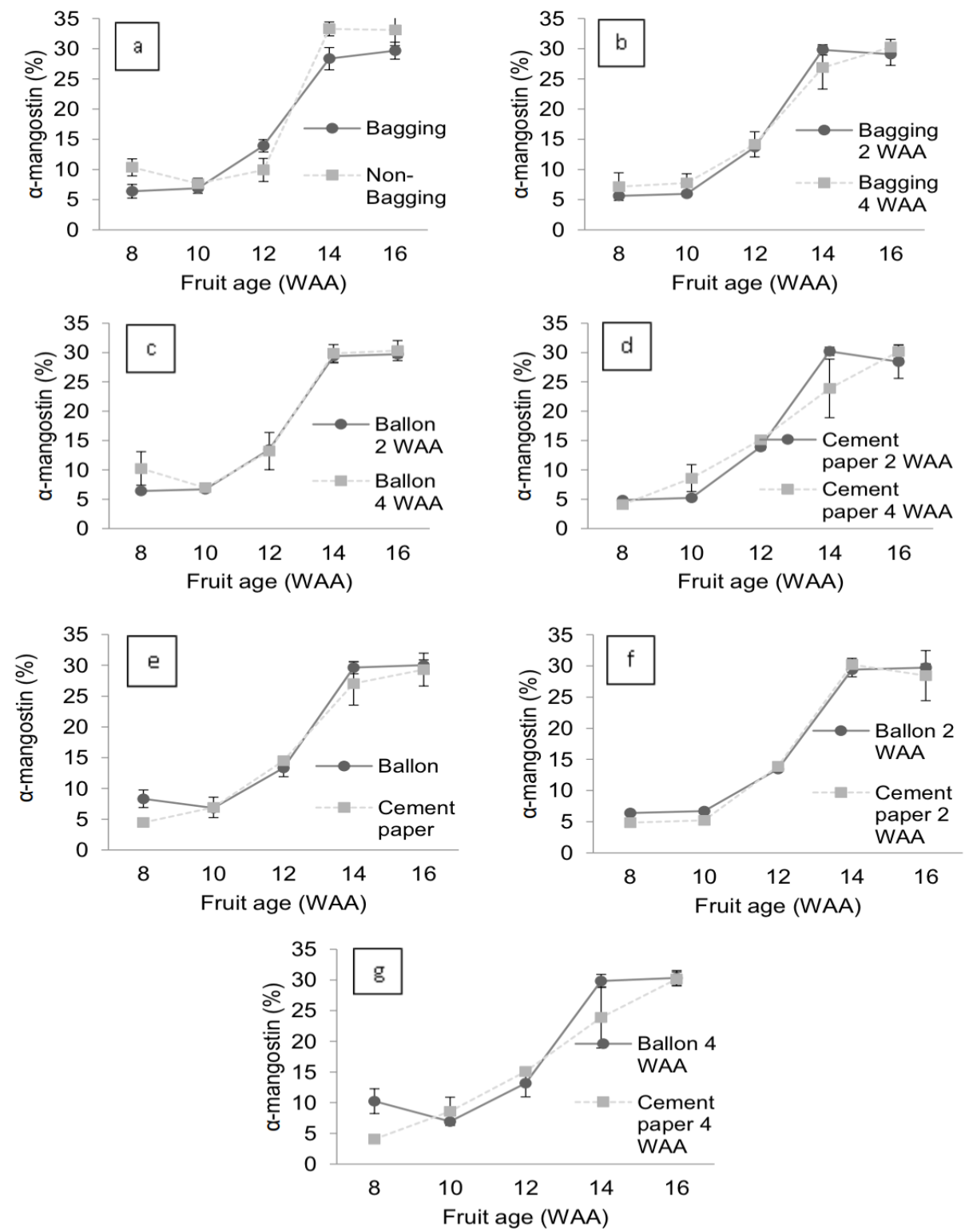

Figure 1. $\alpha$-mangostin content in the mangosteen rind after pre-harvest baggings during fruit growth

manuscript preparations

\section{References}

Aizat, W.M., Ahmad-Hashim, F.H. and Jaafar, S.N.S. (2019). Valorization of mangosteen, the queen of fruits, and new advances in postharvest and in food and engineering applications: a review. Journal of Advanced Research, 20, 61-70. https:// doi.org/10.1016/j.jare.2019.05.005

Arrosyadi, U.L., Astutik, Y.D.P., Pradana, H.A., Islamianti, A.C. and Marfuah, S. (2016). Antioxidant and antihypertensive properties of functional beverages based on decaffeinated coffee and mangosteen rind. The $2^{\text {nd }}$ International Conference on Food Agricultural and Natural Resources, 2-4 August, p. 241 - 251. Brawijaya University, Malang, East Java, Indonesia.

Cunha, B.L.A., de França, J.P., Moraes, A.A.F.S., Chaves, A.L.F, Gaiba, S., Montana, R., de Sacramento, C.K., Ferreira, L.M. and de França, L.P.
(2014). Evaluation of antimicrobial and antitumoral activity of Garcinia mangostana L. (mangosteen) grown in Southeast Brazil. Acta Cirúrgica Brasileira, 29(2), 21-28. https://doi.org/10.1590/ S0102-86502014001400005

Dorly, T.S, da Silva, J.A.T., Poerwanto, R., Efendi, D. and Barasa, F. (2011). Calcium spray reduces yellow latex on mangosteen fruits (Garcinia mangostana L.) Journal of Fruit and Ornamental Plant Research, 19 (2), 51-65.

Dorly, T.S., Poerwanto, R. and Juliarni. (2008). Secretory duct structure and phytochemistry compounds of yellow latex in mangosteen fruit. HAYATI Journal of Biosciences, 15(3), 99-104. https://doi.org/10.4308/hjb.15.3.99

Gondokesumo, M.E., Pardjianto, B., Sumitro, S.B., Widowati, W. and Handono, K. (2019). Xanthones analysis and antioxidant activity analysis (applying ESR) of six different maturity levels of mangosteen rind extract (Garcinia mangostana Linn.). 
Pharmacognosy Journal, 11(2), 369-373. https:// doi.org/10.5530/pj.2019.11.56

Jarimopas, B., Puspariksha, P. and Singh, S.P. (2009). Postharvest damage of mangosteen and quality grading using mechanical and optical properties as indicator. International Journal of Food Properties, 12(2), 414-426. https:// doi.org/10.1080/10942910701837262

Jaritngam, R., Limsakul, C. and Wongkittiserksa, B. (2012). The translucent and yellow gummy latex of mangosteen by using autoregressive coefficient method. Innovative Systems Design and Engineering, 3(5), 33-40.

Jaritngam, R., Limsakul, C., Sdoodee, S., Jaritngam, S. and Mani, M. (2001). To detect gumming fruit of mangosteen (Garcinia mangostana Linn.) by the autoregressive model analysis method. Journal of Agricultural Science, 32, 1-4.

Kurniawati, A., Poerwanto, R., Sobir, Effendi, D. and Cahyana, H. (2010). Evaluation of fruit characters, xanthones content, and antioxidant properties of various qualities of mangosteens (Garcinia mangostana L.). Indonesia Journal of Agronomy, 38 (3), 232-237.

Kurniawati A., Poerwanto, R., Sobir, Efendi, D. and Cahyana, H. (2011). Character, xanthone content and antioxidant properties of mangosteen fruit's hull (Garcinia mangostana L.) at several fruit growth stadia. Indonesia Journal of Agronomy, 39(3),188192.

Lim, T.K. (2012). Edible Medicinal and Non-Medicinal Plants. Vol. 4, Fruits. Netherlands: Springer. https:// doi.org/10.1007/978-94-007-4053-2

Manurakchinakorn, S., Nuymark, P., Phoopouk. P., Poohern, P. and Chamnan, U. (2005). Browning inhibition and firmness retention in fresh-cut mangosteens (Garcinia mangostana L.). Acta Horticulturae, 1682, 1811-1818. https:// doi.org/10.17660/ActaHortic.2005.682.242

Muchtaridi, Suryani, D., Qosim, W.A. and Saptarini, N.M. (2016). Quantitative analysis of $\alpha$-mangostin in mangosteen (Garcinia mangostana L.) pericarp extract from four district of west java by HPLC method. International Journal of Pharmacy and Pharmaceutical Sciences, 8(8), 232-236.

Ngarmsak, M. (2007). Antifungal activity of vanillin on fresh-cut tropical fruits. Acta Horticulturae, 746, 409 -415 .

https://doi.org/10.17660/

ActaHortic.2007.746.50

Pludbuntong, W., Makhonpas, C. and Poovarodom, S. (2007). Nutrient content in translucent flesh and gamboges disorders of mangosteen fruits (Garcinia mangostana L.) presented at the International Conference on Sustainable Technology and Development, 26-27 April, Bangkok, Thailand.

Poovarodom, S. (2010). Calcium and physiological disorders of mangosteen fruits presented at the $16^{\text {th }}$ Asian Agricultural Symposium and $1^{\text {st }}$ International Symposium on Agricultural Technology "Sufficiency Agriculture" 25 - 27 August 2010, Bangkok, Thailand.

Wang, J.J., Sanderson, B.J.S. and Zhang, W. (2011). Cytotoxic effect of xanthones from pericarp of the tropical fruit mangosteen (Garcinia mangostana Linn.) on human melanoma cells. Food and Chemical Toxicology, 49(9), 2385-2391. https:// doi.org/10.1016/j.fct.2011.06.051

Widodo, S.E., Kamal, M., Zulferiyenni, Chandra, D. and Kusuma, D.W. (2019). Flower baggings in affecting mangosteen fruit qualities at harvest and during storage. The $5^{\text {th }}$ International Conference on Science, Technology, and Interdisciplinary Research September 23-25, 2019, Bandar Lampung, Indonesia. 